Vol. 1 No. 2 September 2021 e-ISSN : 2797-3344 P-ISSN : 2797-3336

\title{
PENGEMBANGAN MODUL PEMBELAJARAN BIOLOGI BERORIENTASI MODEL SIKLUS BELAJAR UNTUK SISWA SMA/MA KELAS X
}

\author{
SUCI ILHAMI \\ MAN Insan Cendekia Padang Pariaman, kementerian agama republik indonesia \\ Email: suciilhami07@gmail.com
}

\begin{abstract}
ABSTRAK
Bahan ajar merupakan media pembelajaran yang penting bagi siswa. Berdasarkan hasil observasi yang dilakukan di MAN Lubuk Alung diperoleh informasi bahwa pembelajaran di sekolah masih menggunakan buku pegangan dari perpustakaan dan buku siswa kurikulum 2013 yang sulit dipahami siswa. Pada proses pembelajaran, banyak siswa yang aktif tapi tidak dapat semua yang diberi kesempatan oleh guru dalam menyampaikan pendapat. Berdasarkan uraian latar belakang di atas, maka penulis melakukan penelitian yang bertujuan untuk mengembangkan modul pembelajaran biologi berorientasi model siklus belajar 4E untuk siswa SMA/MA kelas X semester I. Jenis penelitian ini adalah penelitian pengembangan dengan menggunakan IDI models yaitu, define, develop dan evaluate. Modul yang dikembangkan divalidasi oleh 5 orang validator, dan untuk uji praktikalitas dilakukan oleh 2 orang guru dan 30 orang siswa Kelas X MAN Lubuk Alung. Data penelitian ini adalah data primer yang diperoleh dari angket validitas, praktikalitas dan efektivitas kemudian dianalisis dengan analisis deskriptif. Penelitian ini telah menghasilkan produk berupa Modul pembelajaran biologi berorientasi siklus belajar untuk siswa SMA/MA kelas X semester I yang dikembangkan dengan Model pengembangan IDI Model. Modul yang dihasilkan valid baik dari aspek kelayakan isi, kebahasaan, penyajian, maupun aspek kegrafikan. Modul yang dihasilkan juga sudah praktis oleh guru dan siswa dari segi kemudahan penggunaan, waktu pembelajaran, maupun biaya. Kemudian modul juga efektif jika ditinjau dari motivasi, aktifitas dan hasil kompetensi belajar siswa. Dengan demikian dapat disimpulkan bahwa modul pembelajaran biologi berorientasi siklus belajar untuk siswa SMA/MA kelas X semester I memiliki kriteria valid, praktis dan efektif.
\end{abstract}

Kata Kunci: Pengembangan, Modul, Model Siklus Belajar 4E, Materi Pelajaran Semester 1 Kelas X

ABSTRACT

Teaching materials are important learning media for students. Based on observations in MAN Lubuk Alung obtained information that learning in these school are still using tetbooks from the library and 2013 curicullum student books that difficult to understand and after futher asked, not all students have it and wants to borrow. In the learning process, many students were active but were not given the opportunity to express their opinions. Based on the description above, so the authors conducted research that aims to develop biology learning module oriented 4E learning cycle model for SMA/MA students class X semester I. The type of this research is development research by using IDI models that consist of define, develop and evaluate. Module developed validated by five validators and for practilities test conducted by two teachers and thirty students class X MAN Lubuk Alung. The data collected by questionnaire validities, practicalities and effectivities then analyzed with descriptive analysis. The result of this research is biology learning module oriented 4E learning cycle model for SMA/MA students class X semester I developed by the development IDI model. Module produced is valid based on feasibility content, language, presentation and design aspect. Module product also practic by teacher and students based on user, time and price aspect. Then, modul also effectif based on motivation, activities and result of students learning competencies. It can be concluded that the biology learning module oriented 4E learning cycle model for SMA/MA students class X semester I have criteria valid, practic and effective. words.

Keywords: Development, Module, 4E Learning Cycle Model, Class X Semester 1 Subject Matter 


\section{PENDAHULUAN}

Perkembangan teknologi dan informasi serta sumber daya manusia (SDM) merupakan tantangan bagi penyelenggara pendidikan dalam meningkatkan kualitas pendidikan. Berbagai upaya yang telah dilakukan pemerintah salah satunya dengan penggunaan bahan ajar yang baik. Salah satu faktor yang mempengaruhi peningkatan mutu pendidikan adalah peningkatan kualitas pembelajaran (Wena, 2009). Peningkatan kualitas pembelajaran bisa dilakukan langsung dengan tersedianya bahan ajar yang berkualitas. Upaya tersebut bertujuan agar pembelajaran berlangsung secara efektif, efisien, dan memiliki daya tarik yang tinggi khususnya dalam pembelajaran biologi.

Penggunaan media pembelajaran seperti bahan ajar yang tepat diharapkan dapat mengatasi keterbatasan-keterbatasan yang dimiliki oleh siswa, sehingga siswa dapat menerima dan memahami materi pelajaran dengan benar. Penggunaan media pembelajaran dalam menyalurkan pesan dapat membantu mengatasi perbedaan gaya belajar, minat, intelegensi, keterbatasan daya indera, cacat tubuh atau hambatan jarak geografis, jarak waktu dan lain-lain (Sadiman, Rahardjo \& Rahardjito, 2009).

Penulis melakukan observasi dengan mewawancarai guru biologi dan siswa MAN Lubuk Alung serta mewawancarai siswa dari SMA 1 dan SMA 2 Pariaman. Hasil wawancara penulis dengan guru Biologi kelas XI dan XII MAN Lubuk Alung Kabupaten Padang Pariaman yang semester sebelumnya juga mengajar di kelas X, yaitu Ibu Ratna Dewi, S.Pd., M.Si. dan wawancara dengan beberapa siswa kelas X MAN Lubuk Alung, diperoleh informasi bahwa guru belum pernah menggunakan bahan ajar seperti modul dan LKS. Proses pembelajaran di sekolah masih menggunakan buku pegangan dari perpustakaan dan buku siswa kurikulum 2013 yang sulit dipahami siswa dan setelah ditanya lebih lanjut, ternyata tidak semua siswa mempunyai dan mau meminjam buku pegangan tersebut. Mereka hanya bergantung pada penjelasan dari guru dan belum pernah belajar menggunakan modul sebagai bahan ajar yang menjadikan pembelajaran lebih efektif dan efisien.

Pada proses pembelajaran, banyak siswa yang aktif tapi tidak dapat semua yang diberi kesempatan oleh guru dalam menyampaikan pendapat. Hal ini mungkin dikarenakan pemakaian waktu yang relatif lama. Siswa juga selalu tertarik untuk mengamati dan menanya ketika guru memasuki pelajaran. Tapi, guru biologi umumnya belum optimal memanfaatkan konsepsi awal siswa dan lebih banyak memberitahu daripada memberikan bagaimana cara mencari tahu ( menemukan konsep dan prinsip biologi) dalam rancangan pembelajaran maupun implementasi program pembelajarannya di kelas.

Hasil wawancara dari siswa SMA 1 dan SMA 2 Pariaman, mereka tidak pernah belajar menggunakan modul tetapi mereka hanya diberikan Handout pada setiap materi. Handout yang digunakan hanya lembaran-lembaran kertas fotokopian yang tidak membuat siswa begitu tertarik. Handout yang digunakan tidak memiliki komponen bahan ajar yang seharusnya seperti cover, petunjuk penggunaan, dan evaluasi.

Selain itu menurut siswa MAN Lubuk Alung, SMA 1 dan SMA 2 Pariaman, buku pegangan yang selama ini digunakan memiliki kekurangan diantaranya banyaknya kalimat yang meluas dan sedikitnya gambar yang disajikan. Hal ini membuat siswa tidak mampu memahami konsep dari materi dan kurang menarik untuk dibaca.

Materi yang banyak mengalami kesulitan adalah materi semester 1 karena banyak membahas tentang ciri-ciri, klasifikasi, cara reproduksi, dan peranan untuk setiap kingdom. Selain itu, hasil wawancara dengan siswa kelas X MAN Lubuk Alung bahwa secara keseluruhan siswa tersebut mengalami kesulitan pada materi Biologi semester 1 .

Beberapa materi biologi semester 1 membahas tentang Kingdom Archaebacteria dan Eubacteria (Monera), Kingdom Protista dan Kingdom Jamur. Materi ini banyak membahas tentang ciri-ciri morfologi, struktur tubuh, klasifikasi, cara reproduksi dan peranan dari masingmasingnya. Materi ini menuntut siswa untuk memahami konsep yang bersifat abstrak karena siswa tidak bisa melihat objek secara langsung dan membutuhkan media gambar yang representatif. Kesulitan pemahaman konsep juga disebabkan oleh guru yang mengajar dengan 
cara konvensional dan jarang menggunakan media pembelajaran seperti charta yang membantu siswa dalam melihat gambar.

Berkaitan dengan itu, siswa membutuhkan Modul. Hal ini dikarenakan modul lebih bersifat representatif dan fleksibel. Pengajaran modul dapat disesuaikan dengan perbedaan siswa antara lain mengenai kecepatan belajar, cara belajar dan bahan belajar. Modul Dibandingkan dengan handout dan bahan ajar lainnya, Modul memiliki beberapa komponen yaitu cover, petunjuk umum, materi pembelajaran per pertemuan, lembar kerja dan kunci jawaban. Modul juga di desain untuk siswa sehingga akan menimbulkan minat baca. Didalam modul banyak disajikan gambar yang sesuai dengan materi dan kalimat yang lebih sederhana. Modul adalah seperangkat aktivitas yang bertujuan mempermudah siswa untuk mencapai seperangkat tujuan pembelajaran dan Sistem pembelajaran modul akan menjadikan pembelajaran lebih efisien, efektif dan relevan (Wena, 2009). Salah satu solusi dari masalah tersebut adalah siswa diberikan suatu bahan ajar yang komunikatif.

Modul memiliki keunggulan dalam proses penggunaan. Selain bisa digunakan di dalam kelas secara berkelompok, modul juga dirancang dalam pembelajaran individual. Kondisi pembelajaran yang ideal adalah apabila siswa berinteraksi melalui pengalaman yang dirancang secara individual, interaktif, dan tujuan pembelajaran berhasil dicapai(Aliassyah, 2010).

Selain itu, agar siswa semakin mudah memahami materi dan belajar pun bisa menjadi lebih bermakna maka modul juga berorientasi Model siklus belajar. Model ini digunakan karena sesuai dengan karakteristik siswa kelas X MAN tersebut. Sesuai dengan kurikulum K13, pada saat siswa diberi tahapan mengamati, semua siswa sangat tertarik untuk mengetahuinya lebih lanjut. Sehingga pada saat masuk tahapan menanya, siswa dengan semangat menjawab seluruh pertanyaan yang diberikan. Alasan inilah kenapa model pembelajaran siklus belajar digunakan. Dengan model ini, siswa akan diberi kesempatan untuk mengungkapkan seluruh pengetahuan awalnya. Model ini dapat membantu mengoptimalkan pemanfaatan pengetahuan awal siswa dan penemuan konsep sendiri oleh siswa terlebih dahulu. Secara umum, siklus belajar dideskripsikan sebagai suatu model pembelajaran yang berpusat pada kegiatan penyelidikan sebelum pengenalan konsep ilmiah tertentu (Citrawathi, 2006). Proses pembelajaran sebagai siklus empat tahap yang di dalamnya peserta didik memiliki pengalaman tertentu sebagai dasar, observasi dan refleksi mereka terhadap pengalaman tersebut, diasimilasikan ke dalam kerangka konseptual, dan diuji dalam situasi yang berbeda (Huda, 2013). Hal inilah yang menjadikan modul ini menjadi berkarakteristik. Setiap media mempunyai karakteristik tertentu, baik dilihat dari segi keampuhannya, cara pembuatannya, maupun cara penggunaannya (Djamarah dan Zain, 2006).

Berdasarkan uraian latar belakang yang telah dijabarkan di atas, maka penulis mengambil judul "pengembangan modul pembelajaran biologi berorientasi model siklus belajar 4E untuk siswa SMA/MA kelas X semester I".

\section{METODE PENELITIAN}

Jenis penelitian yang digunakan adalah penelitian pengembangan. Penelitian pengembangan dapat menghasilkan produk yang bisa mengatasi masalah yang dihadapi guru dan siswa. Dalam penelitian ini produk yang akan dihasilkan adalah modul pembelajaran biologi berorientasi siklus belajar untuk siswa SMA/MA kelas X semester I.

Dalam penelitian ini peneliti menggunakan model IDI (Instructional Development Institute). Pengembangan model IDI menerapkan prinsip-prinsip pendekatan sistem, yaitu pendefinisian (define), pengembangan (develop), dan penilaian (evaluate) (Yusnita dkk, 2011).

Prosedur penelitian terdiri dari 3 tahapan yaitu tahap define, tahap develop, dan tahap evaluate. Tahap define bertujuan untuk menentukan masalah dasar yang dibutuhkan dalam mengembangkan media pembelajaran biologi sehingga dapat menjadi alternatif media pembelajaran yang sesuai.tahap define dilakukan dengan melakukan analisis muka-belakang yang bertujuan untuk mempelajari dan menetapkan masalah dasar yang dihadapi siswa. 
Analisis ini dilakukan melalui wawancara teman sejawat, analisis silabus mata pelajaran, review literatur dan analisis siswa.

Tahap develop bertujuan untuk menghasilkan suatu bentuk modul pembelajaran biologi yang telah direvisi berdasarkan masukan validator dan dosen pembimbing, sehingga didapatkan suatu perangkat yang dapat diuji cobakan. Tahapan ini dilakukan dengan Uji validitas dan uji praktikalitas. Pada uji validitas terdapat poin-poin yang akan dinilai diantaranya: kelayakan isi, kebahasaan, penyajian, dan kegrafikan. Pada uji praktikalitas terdapat poin-poin yang akan dinilai diantaranya: kemudahan penggunaan, manfaat dan efektivitas waktu.

Tahapan evaluate dilihat dari aspek efektivitas modul. Aspek efektivitas yang diamati dalam proses pembelajaran yang menggunakan modul pembelajaran biologi berorientasi siklus belajar untuk siswa SMA/MA kelas X semester I di kelas uji coba adalah motivasi, aktivitas dan hasil belajar siswa.

Uji coba modul dilakukan pada uji coba terbatas yaitu kelas 30 Orang siswa kelas $\mathrm{X}$ MIA 3. Uji coba modul dilakukan kepada siswa kelas X dan guru biologi MAN Lubuk Alung sebagai responden yang mengisi kuisioner/angket yang terpilih menjadi sampel penelitian. Data dalam penelitian ini adalah data primer, yaitu data yang diperoleh secara langsung dari dosen, guru dan siswa yang diambil melalui angket uji validitas, praktikalitas, aktifitas siswa, motivasi siswa dan penilaian hasil belajar .

Instrument yang digunakan untuk mengumpulkan data dalam penelitian ini adalah lembar validasi modul oleh dosen dan guru, angket uji praktikalitas modul yang diisi oleh guru biologi dan angket uji praktikalitas modul yang diisi oleh siswa, angket motivasi yang diisi oleh siswa serta angket aktivitas dan hasil belajar yang diisi oleh guru.

Untuk mengukur hasil belajar siswa, maka peneliti menggunakan instrumen berupa angket dan soal tes. Angket yaitu pengumpulan data melalui penyebaran seperangkat pernyataan maupun pertanyaan tertulis. Angket yang digunakan bertujuan untuk mengumpulkan informasi hasil belajar siswa pada penilaian sikap dan karya yang dibuat siswa sesuai dengan indikator dari Kompetensi inti, sedangkan instrumen berupa soal tes digunakan untuk mengetahui hasil belajar siswa pada ranah kognitif. Untuk mengetahui valid atau tidaknya tes maka dilanalisa dengan validitas isi. Untuk mengetahui validitas tes, dilakukan dengan pengujian indeks kesukaran tes, daya beda dan reliabilitas tes.

Hasil ranah sikap diperoleh dari instrumen pengamatan penilaian sikap siswa. Indikator yang ditetapkan adalah bekerjasama, jujur, ilmiah, teliti dan aktif. Hasil ranah keterampilan diperoleh dari instrumen pengamatan penilaian keterampilan siswa. Kegiatan yang diambil selama penilaian ranah keterampilan adalah Praktikum.

Data penelitian dianalisis dengan menggunakan statistik deskriptif yaitu analisis uji validitas, analisis uji praktikalitas dan analisis uji efektivitas yang mencakup analisis data angket motivasi. analisis data hasil observasi aktivitas dan analisis data hasil belajar.

\section{HASIL DAN PEMBAHASAN}

\section{Hasil}

Berdasarkan tujuan dan prosedur penelitian, maka dihasilkan modul pembelajaran biologi berorientasi model siklus belajar untuk siswa SMA/MA kelas X , dan diperoleh hasil validasi modul oleh guru dan dosen, praktikalitas modul oleh guru dan siswa, serta efektivitas oleh siswa.

Pertama, pada tahap define dilakukan wawancara teman sejawat melalui wawancara dengan guru dan siswa. Dari kegiatan tersebut, diperoleh informasi bahwa siswa masih menggunakan buku pegangan yang sulit dipahami dan setelah ditanya lebih lanjut, ternyata tidak semua siswa mempunyai buku pegangan tersebut. Mereka hanya bergantung pada penjelasan dari guru dan belum pernah belajar menggunakan modul. Selain itu, siswa mengalami kesulitan memahami materi pada semester I. Materi ini menuntut siswa untuk memahami konsep yang bersifat abstrak karena siswa tidak bisa melihat objek secara langsung dan membutuhkan media gambar yang representatif. Oleh karena itu, perlu dikembangkan 
bahan ajar tertulis berupa modul pembelajaran biologi berorientasi model siklus belajar untuk siswa SMA/MA kelas X.

Selanjutnya hasil analisis silabus mata pelajaran biologi diperoleh beberapa keterangan bahwa pembelajaran dilakukan dengan kurikulum 2013 serta hasil analisis yang berhubungan dengan KI, KD dan indikator. Kemudian dilakukan review literatur dan didapatkan bahwa buku yang dipakai oleh siswa adalah buku paket dari berbagai penerbit seperti Erlangga dan lainnya. Susunan materi sudah sesuai dengan silabus yang berlaku. Materi yang diberikan tentang Archaebacteria eubacteria, protista dan fungi terlalu panjang dan perlu lebih singkat dan jelas. Evaluasi yang diberikan sudah sesuai indikator. Hal yang tidak ada pada literatur yang sudah ada adalah penerapan langsung metode atau model pembelajaran.

Terakhir melakukan kegiatan analisis siswa untuk menelaah karakteristik siswa yang akan dijadikan sebagai objek penelitian. Analisis siswa yang digunakan adalah analisis usia. Usia siswa saat duduk di SMA/MAN kelas X umumnya adalah 15-16 tahun berarti sudah termasuk kategori individu yang telah mampu mengembangkan potensi psikomotornya sehingga lebih terampil dalam penggunaan media seperti bahan ajar berupa modul.

Kedua, pada tahap develop yang dilakukan adalah merancang dan memvalidasi modul pembelajaran biologi berorientasi model siklus belajar untuk siswa SMA/MA kelas X. pada perancangan modul dilakukan pemilihan media. Media yang dikembangkan adalah bahan ajar berupa modul yang memuat materi tentang Archaebacteria dan Eubacteria, Protista dan Fungi. Materi atau konsep yang terdapat dalam materi ini disajikan dengan banyak gambar berwarna yang menarik perhatian siswa. Selain itu, Modul juga dirancang berorientasi model siklus belajar. Penggunaan model siklus belajar ini dapat membantu mengoptimalkan pemanfaatan pengetahuan awal siswa dan penemuan konsep sendiri oleh siswa terlebih dahulu. tiap-tiap kegiatan belajar pada modul berisikan 4 tahapan yang menggambarkan model siklus belajar yaitu tahap eksplorasi, tahap eksplanasi, tahap ekspansi dan tahap evaluasi.

Modul diformat dengan menentukan beberapa komponen yang terdapat di dalam modul seperti cover yang berisi judul, daftar isi, daftar gambar, kompetensi inti, kompetensi dasar, indikator, petunjuk belajar, lembaran materi per pertemuan, evaluasi,lembar praktikum, kunci jawaban dan daftar pustaka.

Selanjutnya, Uji validitas modul yang dilakukan oleh 3 orang dosen pascasarjana UNP diantaranya dosen biologi, dosen teknologi pendidikan dan dosen bahasa Indonesia serta 2 orang guru biologi MAN Lubuk Alung dengan menggunakan lembar validitas. Secara ringkas analisis hasil validitas ditampilkan pada Tabel 1.

Tabel 1. Analisis Data Hasil Uji Validitas modul

\begin{tabular}{|l|l|c|c|}
\hline \multirow{2}{*}{ No } & \multicolumn{1}{|c|}{ Komponen Penilaian } & Nilai validitas $(\%)$ & Kriteria \\
\hline & Kelayakan isi & $89,17 \%$ & Valid \\
\hline & Komponen kebahasaan & $82 \%$ & Valid \\
\hline & Komponen penyajian & $89 \%$ & Valid \\
\hline & Komponen kegrafikan & $85 \%$ & Valid \\
\hline Total & $345,17 \%$ & \\
\hline Rata-rata & $86,29 \%$ & Valid \\
\hline
\end{tabular}

1. Tahap Evaluate

a. Uji praktikalitas modul

1) Praktikalitas modul pembelajaran biologi berorientasi model siklus belajar oleh guru biologi MAN Lubuk Alung. 
Tabel 4. Hasil uji praktikalitas modul pembelajaran biologi berorientasi model siklus oleh guru biologi MAN Lubuk Alung.

\begin{tabular}{|l|l|c|l|}
\hline No & Aspek & Nilai Praktikalitas $(\%)$ & Kriteria \\
\hline & Kemudahan penggunaan & 96,42 & Sangat praktis \\
\hline & Waktu & 81,25 & Praktis \\
\hline & Biaya & 87,50 & Praktis \\
\hline Total & 265,17 & \\
\hline Rata-rata & 88,39 & Praktis \\
\hline
\end{tabular}

Tabel 4 dapat dilihat bahwa secara umum penilaian tingkat kepraktisan modul pembelajaran biologi berorientasi model siklus oleh guru biologi MAN Lubuk Alung adalah sangat praktis dengan rata-rata nilai praktikalitas 88,39\%. Berdasarkan aspek penilaian yang terdapat pada uji praktikalitas maka modul pembelajaran biologi berorientasi model siklus yang dihasilkan termasuk ke dalam kriteria sangat praktis untuk digunakan dari aspek kemudahan dalam penggunaan, sedangkan praktis dinilai dari aspek waktu dan biaya.

2) Praktikalitas modul pembelajaran biologi berorientasi model siklus oleh siswa kelas X MAN Lubuk Alung

Uji praktikalitas juga dilakukan kepada siswa MAN di kelas X MIA 3 sebanyak 30 orang siswa.

Tabel 5. Hasil Uji Praktikalitas Modul oleh Siswa

\begin{tabular}{|l|l|c|l|}
\hline No & \multicolumn{1}{|c|}{ Aspek } & Nilai Praktikalitas $(\%)$ & Kriteria \\
\hline 1 & Kemudahan penggunaan & 91,78 & Sangat praktis \\
\hline 2 & Waktu & 84,58 & Praktis \\
\hline 3 & Biaya & 90,83 & Sangat Praktis \\
\hline \multicolumn{2}{|c|}{ Total } & 267,19 & \\
\hline & Rata-rata & 89,06 & Praktis \\
\hline
\end{tabular}

Dari Tabel 5 dapat dilihat bahwa secara umum hasil uji praktikalitas oleh siswa terhadap modul pembelajaran biologi berorientasi model siklus adalah praktis dengan rata-rata nilai praktikalitas $89,06 \%$. Berdasarkan kriteria yang terdapat pada uji praktikalitas, maka modul yang dihasilkan termasuk ke dalam kriteria sangat praktis dari aspek kemudahan dalam penggunaan dan biaya. Sedangkan dari aspek waktu termasuk kriteria praktis.

b. Uji Efektifitas Modul

Tingkat keberhasilan dari penggunaan modul pembelajaran biologi berorientasi model siklus belajar dilakukan dengan melihat motivasi belajar siswa, mengamati aktivitas siswa dalam pembelajaran dan melihat hasil belajar siswa yang meliputi aspek pengetahuan, sikap dan keterampilan.

1) Motivasi belajar siswa

Untuk mengetahui motivasi siswa, mereka diminta untuk mengisi angket motivasi belajar. Angket motivasi diberikan setelah pembelajaran dengan menggunakan modul pembelajaran biologi berorientasi model siklus belajar sebanyak 4 kali pertemuan.

Tabel 6. Data Skor Hasil Lembar Motivasi Belajar Siswa

\begin{tabular}{|l|l|l|l|}
\hline No & Indikator & Persentase (\%) & kategori \\
\hline 1 & Minat/perhatian & 87,29 & Sangat tinggi \\
\hline 2 & Relevan & 90,27 & Sangat tinggi \\
\hline 3 & Harapan/keyakinan & 86,04 & Sangat tinggi \\
\hline
\end{tabular}


Vol. 1 No. 2 September 2021 e-ISSN : 2797-3344 P-ISSN : 2797-3336

\begin{tabular}{|l|l|l|l|}
\hline 4 & kepuasan & 86,45 & Sangat tinggi \\
\hline Rata-rata & 87,50 & Sangat tinggi \\
\hline
\end{tabular}

Berdasarkan Tabel 6 diketahui bahwa dari empat indikator motivasi belajar siswa berdasarkan angket siswa yaitu minat/perhatian, relevan, harapan/keyakinan, dan kepuasan menunjukkan skor nilai rata-rata 87,50\% dengan katergori sangat tinggi. Dengan demikian jika ditinjau dari motivasi belajar siswa, maka efektifitas penggunaan modul pembelajaran biologi berorientasi model siklus belajar tergolong kategori sangat efektif dalam pembelajaran.

2) Aktivitas siswa

Pengamatan aktivitas belajar dilakukan setiap kali pertemuan selama pembelajaran dengan menggunakan modul yaitu 4 kali pertemuan. Aspek yang diamati selama pembelajaran yaitu aktivitas tanya jawab dengan guru, aktivitas tanya jawab antar siswa, aktivitas memperhatikan dan mengikuti pembelajaran dengan serius, aktivitas dalam melakukan kegiatan diskusi, dan aktivitas mengerjakan soalsoal yang terdapat dalam modul.

Tabel 7. Hasil pengamatan aktivitas belajar siswa kelas X MIA 3

\begin{tabular}{|l|l|l|l|}
\hline $\begin{array}{l}\mathrm{N} \\
\mathrm{o}\end{array}$ & Aspek yang diamati & Persentase (\%) & kategori \\
\hline 1 & aktivitas tanya jawab dengan guru & 77,5 & Sangat Efektif \\
\hline 2 & aktivitas tanya jawab antar siswa & 72,9 & Efektif \\
\hline 3 & $\begin{array}{l}\text { aktivitas memperhatikan dan mengikuti } \\
\text { pembelajaran dengan serius }\end{array}$ & 83,32 & Sangat Efektif \\
\hline 4 & $\begin{array}{l}\text { aktivitas dalam melakukan kegiatan } \\
\text { diskusi }\end{array}$ & 62,5 & Efektif \\
\hline 5 & $\begin{array}{l}\text { aktivitas mengerjakan soal-soal yang } \\
\text { terdapat dalam modul }\end{array}$ & 82,9 & Sangat Efektif \\
\hline Rata-rata & 76 & Sangat Efektif \\
\hline
\end{tabular}

Berdasarkan Tabel 7 diketahui bahwa dari lima aspek aktivitas belajar siswa berdasarkan pengamatan observer menunjukkan skor nilai rata-rata $76 \%$ dengan katergori sangat aktif. Dengan demikian jika ditinjau dari motivasi belajar siswa, maka efektifitas penggunaan modul pembelajaran biologi berorientasi model siklus belajar tergolong kategori sangat efektif dalam pembelajaran.

3) Hasil belajar siswa

a) Hasil belajar aspek pengetahuan

Hasil belajar aspek pengetahuan diperoleh dari ujian yang diberikan berupa tes tertulis dalam bentuk soal objektif. Tes dilakukan setelah pembelajaran menggunakan modul pembelajaran biologi berorientasi model siklus belajar. Dari hasil tes siswa kelas X MIA 3 MAN Lubuk Alung yang berjumlah 30 orang diperoleh nilai 92,5 dengan rata-rata 3,7. Persentase siswa yang memperoleh nilai $\geq 2,67$ adalah $86 \%$ berada diatas standar nilai Kurikulum 2013. Dapat disimpulkan bahwa efektivitas penggunaan modul pembelajaran biologi berorientasi model siklus belajar di MAN Lubuk Alung termasuk kategori efektif.

b) Hasil belajar aspek sikap

penilaian dilakukan selama pembelajaran menggunakan modul pembelajaran biologi berorientasi model siklus belajar sebanyak empat kali pertemuan. Adapun aspek penilaian sikap yaitu bekerja sama, jujur, teliti, dan aktif. 
Tabel 8. Hasil Belajar Ranah Sikap Siswa Kelas X Mia 3 MAN Lubuk Alung.

\begin{tabular}{|l|l|l|l|l|}
\hline No & Pertemuan & Rata-rata & Kriteria & kategori \\
\hline 1 & 1 & 3,4 & B (Baik) & Efektif \\
\hline 2 & 2 & 3,6 & B (Baik) & Efektif \\
\hline 3 & 3 & 3,6 & B (Baik) & Efektif \\
\hline 4 & 4 & 3,5 & B (Baik) & Efektif \\
\hline $\begin{array}{l}\text { Rara-rata } \\
\text { keseluruhan }\end{array}$ & 3,5 & B (Baik) & Efektif \\
\hline
\end{tabular}

Berdasarkan Tabel 8 diatas, terlihat bahwa nilai hasil belajar aspek sikap pada siswa kelas X Mia 3 MAN Lubuk Alung menggunakan modul pembelajaran biologi berorientasi model siklus belajar berada pada kategori baik dengan nilai rata-rata 3,5. Penilaian aspek sikap ini berkaitan dengan KI 2 yang berhubungan dengan materi pembelajaran. Dari data di atas menunjukkan bahwa pembelajaran dengan menggunakan modul pembelajaran biologi berorientasi model siklus belajar dapat meningkatkan hasil belajar pada aspek sikap, maka efektivitas penggunaan modul pembelajaran biologi berorientasi model siklus belajar ini tergolong kategori efektif.

c) Hasil belajar aspek keterampilan

Penilaian dilakukan selama pembelajaran menggunakan modul pembelajaran biologi berorientasi model siklus belajar sebanyak dua kali pertemuan yaitu pada saat praktikum dilakukan. Adapun aspek penilaian keterampilan yaitu pemilihan alat/bahan praktikum, urutan kegiatan praktikum dan produk.

Tabel 9. Hasil Belajar Ranah keterampilan Siswa Kelas X Mia 3 MAN Lubuk Alung

\begin{tabular}{|l|l|l|l|l|l|}
\hline No & Praktikum & $\begin{array}{l}\text { Rata- } \\
\text { rata }\end{array}$ & Nilai & Kriteria & kategori \\
\hline 1 & Protista & 10,2 & 90 & Baik & Efektif \\
\hline 2 & Fungi & 11,4 & 90 & Baik & Efektif \\
\hline $\begin{array}{l}\text { Rata-rata } \\
\text { keseluruhan }\end{array}$ & 10,8 & 90 & Baik & Efektif \\
\hline
\end{tabular}

Berdasarkan Tabel 9 diatas, terlihat bahwa nilai hasil belajar aspek keterampilan pada siswa kelas X Mia 3 MAN Lubuk Alung menggunakan modul pembelajaran biologi berorientasi model siklus belajar berada pada kategori baik dengan nilai rata-rata 90. Penilaian aspek sikap ini berkaitan dengan KI 4 yang berhubungan dengan materi pembelajaran. Dari data di atas menunjukkan bahwa pembelajaran dengan menggunakan modul pembelajaran biologi berorientasi model siklus belajar dapat meningkatkan hasil belajar pada aspek keterampilan, maka efektivitas penggunaan modul pembelajaran biologi berorientasi model siklus belajar ini tergolong kategori efektif.

\section{Pembahasan}

1. Validitas Modul

Analisis data hasil validitas menunjukkan bahwa modul pembelajaran biologi berorientasi model siklus yang dihasilkan memenuhi kriteria valid. Hal ini didasarkan pada uji validitas modul yang meliputi empat aspek, yaitu aspek kelayakan isi, aspek komponen kebahsaan, komponen penyajian, komponen kegrafikan. Empat aspek ini sesuai dengan kriteria yang ditentukan oleh Depdiknas.

Dari aspek kelayakan isi, modul pembelajaran biologi berorientasi model siklus dinyatakan valid oleh validator setelah mengalami revisi dan sesuai dengan kurikulum yang 
berlaku. Hal ini dilihat berdasarkan lembaran validitas modul pembelajaran biologi berorientasi model siklus yang diisi oleh validator. Selain itu, juga dapat dilihat pada tabel 4 , bahwa nilai validitas aspek kelayakan isi termasuk kriteria valid. Oleh sebab itu, modul pembelajaran biologi berorientasi model siklus dapat dijadikan media pembelajaran dalam proses pembelajaran di MA. Hal ini sesuai dengan penilaian validitas oleh Purwanto (2009: 82) yang telah dimodifikasi bahwa rentang nilai $80 \%-89,99 \%$ termasuk kriteria valid.

Dari aspek kebahasaan, modul pembelajaran biologi berorientasi model siklus dinilai valid oleh validator dengan sedikit revisi yang diberikan validator. Aspek kebahasaan berkaitan dengan penggunaan kaidah bahasa Indonesia yang baik dan benar. Kalimat yang digunakan dalam modul sederhana, jelas dan tidak menimbulkan kerancuan agar siswa mudah memahami informasi yang disampaikan. Hal ini sesuai dengan pendapat Sudjana dan Rivai (2011: 2) bahwa, bahan ajar yang jelas maknanya akan dapat dipahami siswa dan memungkinkan siswa menguasai tujuan pembelajaran dengan lebih baik.

Aspek penyajian modul juga dinilai valid oleh validator. Hal ini, menunjukkan komposisi modul disajikan jelas dan lengkap sesuai materi dengan sedikit revisi yang diberikan validator. Indikator dan tujuan pembelajaran disajikan dengan jelas. Materi sesuai urutan indikator dan lengkap sehingga dapat mendukung pemahaman konsep. Sumber gambar dicantumkan dan latihan dapat mengukur ketercapaian kompetensi. Kelengkapan dan kesesuaian penyajian modul bertujuan agar mendukung pemahaman siswa terhadap isi modul. Hal ini sesuai dengan pernyataan Prastowo (2011: 56) bahwa, hal utama yang dilakukan dalam kriteria kesesuaian adalah memahami kesesuaian sumber belajar yang akan dipilih dengan kompetensi yang mesti dicapai oleh siswa.

Ditinjau dari aspek kegrafikan, modul pembelajaran biologi berorientasi siklus belajar termasuk kriteria valid. Hal ini menunjukkan bahwa tampilan modul baik sehingga mendorong minat baca siswa. Di dalam modul, gambar disajikan dengan warna yang sesuai dan jelas agar dapat menyampaikan pesan secara efektif. Selain itu, penggunaan warna pada background, jenis dan ukuran font pada tulisan dan tata letak disesuaikan agar menjadi lebih menarik dan menumbuhkan semangat belajar siswa. Hal ini sejalan dengan pernyataan Muslich (2008: 68) bahwa, sumber belajar yang menarik dan cukup untuk mendukung kelancaran proses pembelajaran akan menumbuhkan semangat belajar siswa.

Secara keseluruhan dari nilai rata-rata hasil validitas modul yang telah dikembangkan dinyatakan valid dan dapat digunakan oleh siswa dan guru dalam pembelajaran biologi pada materi archaebacteria dan eubacteria, Protista dan Fungi di SMA/MA. Revisi yang dilakukan terkait dengan keempat aspek adalah memberikan warna gambar dengan warna latar yang kontras, memberi Frame yang cocok, memperhatikan EYD yang benar, warna background lebih baik berwarna putih dan warna gambar dan cover yang menarik serta ukuran huruf serasi dan menarik sehingga lebih jelas.

\section{Praktikalitas Modul}

Analisis data hasil uji praktikalitas oleh guru dan siswa MAN Lubuk Alung menunjukkan bahwa modul pembelajaran biologi berorientasi model siklus belajar yang dihasilkan memenuhi kriteria praktis oleh guru dan siswa. Hal tersebut menunjukkan bahwa modul pembelajaran biologi berorientasi model siklus belajar ini praktis digunakan oleh guru dan siswa dalam pembelajaran dari aspek kemudahan dalam proses penggunaan, aspek waktu pembelajaran, dan aspek biaya. Hasil kepraktisan ini didukung oleh respon positif guru yang mengisi angket dan siswa yang menyatakan bahwa modul pembelajaran biologi berorientasi model siklus belajar ini sangat bagus, menarik serta berguna untuk menunjang proses pembelajaran. Hal ini sesuai dengan pernyataan Prastowo (2011: 77), bahan cetak adalah sejumlah bahan yang disiapkan dalam kertas yang dapat berfungsi untuk keperluan pembelajaran/penyampaian informasi.

Dari aspek kemudahan penggunaan, modul dikategorikan sangat praktis oleh guru dan siswa. Hal ini menunjukkan bahwa modul yang dikembangkan mudah digunakan karena memiliki petunjuk belajar yang jelas, tersusun jelas dan sistematis sehingga mudah dipahami, 
Kalimat dan gambar yang digunakan jelas dan mudah untuk dipahami, serta modul bisa digunakan sewaktu-waktu oleh siswa. Hal ini dinyatakan oleh Steffen-Peter Ballstaedt dalam Depdiknas (2008: 18) bahwa, bahan ajar cetak harus memperhatikan bahasa yang mudah dimengerti, kalimatnya jelas dan tidak terlalu panjang. Penggunaan modul mudah sehingga praktis. Modul juga mudah dibawa kemana-mana karena tidak terlalu tebal dan berat.

Dari aspek waktu penggunaan, modul dinilai praktis oleh guru dan siswa. Hal ini menunjukkan bahwa waktu penggunaan modul dalam proses pembelajaran praktis. Penggunaan modul dapat mengefisienkan waktu pembelajaran karena menghindari adanya penjelasan secara berulang-ulang. Selain itu, soal latihan dapat dikerjakan siswa dengan tidak menggunakan waktu yang lama. Hal ini dinyatakan oleh Sukardi (2011: 52) bahwa, salah satu pertimbangan kepraktisan yang perlu diperhatikan untuk instrument evaluasi adalah waktu yang diperlukan untuk proses pelaksanaannya sebaiknya singkat, cepat dan tepat.

Dari aspek biaya, modul dinilai praktis oleh guru dan dinilai sangat praktis oleh siswa. Hal ini menunjukkan bahwa biaya untuk memperoleh modul dapat terjangkau oleh guru dan siswa. Hal ini sesuai dengan pernyataan Prastowo (2011: 61) bahwa, salah satu kriteria pemilihan sumber belajar secara umum adalah ekonomis, artinya sumber belajar tidak mahal dan dengan harga terjangkau.

Secara keseluruhan, untuk praktikalitas modul pembelajaran biologi berorientasi model siklus belajar oleh guru dan siswa termasuk ke dalam kategori praktis. Nilai praktikalitas tersebut menunjukkan bahwa modul mudah digunakan oleh guru dan siswa, dapat mengefisienkan waktu pembelajran dan modul mudah diperoleh dengan biaya yang terjangkau oleh guru dan siswa.

3. Efektivitas Modul

Keefektifan modul pada penelitian ini dilihat dari kemampuan modul sebagai bahan ajar untuk mengaktifkan siswa dalam belajar dan memudahkan pemahaman siswa terhadap materi pelajaran. Pada penelitian ini, keefektifan ditinjau dari motivasi, aktivitas dan hasil belajar (pengetahuan, sikap dan keterampilan).

a. Motivasi belajar siswa

Motivasi belajar siswa yang di amati terdiri dari empat indikator. Pertama, minat siswa dalam belajar menggunakan modul pembelajaran biologi berorientasi model siklus belajar. Kedua, isi modul pembelajaran biologi berorientasi model siklus belajar. Ketiga, harapan siswa setelah proses belajar menggunakan modul pembelajaran biologi berorientasi model siklus belajar. Keempat, tingkat kepuasan siswa setelah proses belajar menggunakan modul pembelajaran biologi berorientasi model siklus belajar. Menurut Sadirman (2012:75) motivasi merupakan kese; luruhan gaya penggerak di dalam diri siswa yang menimbulkan kegiatan belajar, yang menjamin kelangsungan dari kegiatan belajar dan memberikan arah pada kegiatan belajar, sehingga tujuan yang dikehendaki oleh subjek belajar itu dapat tercapai.

Secara rinci, hasil analisis untuk melihat minat siswa dalam belajar dengan menggunakan modul pembelajaran biologi berorientasi siklus belajar pada materi Monera, Protista dan Fungi didapatkan rata-rata yang menunjukkan kriteria sangat efektif. Hasil analisis untuk melihat kesesuaian kebutuhan dan kondisi siswa terhadap keterkaitan isi modul dengan materi pelajaran didapatkan rata-rata yang menunjukkan kriteria sangat efektif. Hasil analisis untuk melihat harapan siswa terhadap pembelajaran dengan menggunakan modul pembelajaran biologi berorientasi siklus belajar pada materi Monera, Protista dan Fungi didapatkan rata-rata yang menunjukkan kriteria sangat efektif. Hasil analisis untuk melihat kepuasan siswa terhadap pembelajaran dengan menggunakan modul pembelajaran biologi berorientasi siklus belajar pada materi Monera, Protista dan Fungi didapatkan rata-rata yang menunjukkan kriteria sangat praktis.

Jadi, analisis data hasil pengamatan motivasi belajar siswa oleh dua orang pengamat menunjukkan bahwa modul pembelajaran biologi berorientasi model siklus belajar yang dihasilkan memenuhi kriteria sangat efektif dalam meningkatkan motivasi belajar siswa. 


\section{b. Aktivitas belajar siswa}

Berdasarkan data hasil pengamatan aktivitas 30 orang siswa yang dilakukan oleh dua orang pengamat menunjukkan kriteria baik. Aktivitas belajar siswa menggunakan modul pembelajaran biologi berorientasi model siklus belajar menggunakan 5 indikator pengamatan. Pertama, siswa aktif tanya jawab dengan guru dengan rata-rata yang menunjukkan kategori sangat aktif. Kedua, siswa aktif tanya jawab antar siswa dengan rata-rata yang menunjukkan kategori aktif. Ketiga, siswa memperhatikan dan mengikuti proses pembelajaran dengan serius dengan rata-rata yang menunjukkan kategori sangat aktif. Keempat, siswa aktif dalam melakukan kegiatan diskusi dengan rata-rata yang menunjukkan kategori aktif. Kelima, siswa mengerjakan soal-soal yang terdapat dalam modul dengan rata-rata yang menunjukkan kategori sangat aktif.

Berdasarkan hasil diatas menunjukkan bahwa penggunaan modul pembelajaran biologi berorientasi model siklus belajar sangat berpengaruh positif pada aktivitas belajar siswa. Semakin tinggi aktivitas siswa maka akan semakin tinggi tingkat pengalaman belajar siswa. Hal ini sesuai dengan Sanjaya (2010: 132) bahwa aktivitas siswa dalam pembelajaran akan memberikan nilai positif untuk pengalaman belajar siswa karena proses pembelajaran bukanlah hafalan melainkan perbuatan.

c. Hasil belajar siswa

Dalam melaksanakan suatu kegiatan pembelajaran, hasil belajar siswa merupakan keluaran yang selalu diharapkan oleh orang-orang yang terlibat dalam proses pembelajaran tersebut baik bagi guru, siswa maupun bagi orangtua siswa. Hasil belajar yang akan diukur meliputi 3 ranah yaitu ranah pengetahuan, ranah sikap dan ranah keterampilan. Tujuan dari hasil penilaian hasil belajar adalah untuk mengukur seberapa jauh tingkat pemahaman yang sudah dikuasai oleh siswa. Trianto (2010: 123) menyatakan bahwa penilaian pembelajaran merupakan serangkaian kegiatan untuk memperoleh, menganalisa dan menafsirkan data tentang proses dan hasil belajar siswa yang dilakukan secara sistematis dan berkesinambungan.

\section{1) Aspek Pengetahuan}

Penialaian hasil belajar aspek pengetahuan bertujuan untuk mengembangkan kemampuan penalaran. Penialaian menggunakan rentang satu sampai empat dan 2,67 batas ketuntasan. Hal ini sesuai dengan Permendikbud (No 104: 2014) bahwa Ketuntasan Belajar untuk pengetahuan ditetapkan dengan skor rerata 2,67. Rata-rata hasil belajar siswa kelas X MIA 3 MAN Lubuk Alung pada materi Protista dan Fungi dapat dikategorikan tuntas berdasarkan batas ketuntasan kurikulum 2013. Dari 30 siswa yang mengikuti tes tersebut terdapat 25 yang memiliki nilai tuntas dan lima orang yang tidak tuntas. Dengan demikian $86 \%$ siswa tuntas dalam materi protista dan fungi.

Menurut depdikbud (1996 dalam Trianto, 2010: 241) bahwa setiap siswa dikatakan tuntas dalam satu kelas jika siswa dalam kelas tersebut tuntas $\geq 85 \%$. Dengan demikian dapat disimpulkan pembelajaran dengan modul pembelajaran biologi berorientasi model siklus belajar dapat meningkatkan hasil belajar siswa, hal ini terlihat dari perolehan nilai yang dicapai siswa.

\section{2) Aspek Sikap}

Penialaian hasil belajar aspek sikap bertujuan untuk mengembangkan kemampuan afektif dalam pembelajaran. Menurut Djamarah (2003: 149) menyatakan bahwa ciri dari perkembangan afektif adalah menyangkut sikap dan perasaan serta dorongan dalam hati untuk berbuat sesuatu, misalnya rasa ingin tahu, tertarik pada tugas-tugas yang diberikan dan dirasakan sebagai tantangan serta menghargai diri sendiri dan orang lain. Kompetensi inti yang mengacu kepada penilaian sikap adalah kompetensi inti kedua. Tetapi penilaian dibatasi sesuai dengan materi yang dipelajari. Indikator yang digunakan adalah bekerjasama, jujur, teliti dan aktif. 
Penilaian sikap dilakukan secara Observasi yang menggunakan rentang satu sampai empat. Pada kurikulum 2013 sistem penilaian sikap dilihat dari nilai yang sering muncul di antara keempat indikator (modus). Hal ini sesuai dengan Permendikbud (No 104 : 2014) bahwa Ada beberapa cara yang dapat digunakan untuk menilai sikap peserta didik, antara lain melalui observasi, penilaian diri, penilaian teman sebaya, dan penilaian jurnal. Instrumen yang digunakan antara lain daftar cek atau skala penilaian (rating - 13 - scale) yang disertai rubrik, yang hasil akhirnya dihitung berdasarkan modus. Rata-rata nilai sikap siswa kelas X MIA 3 MAN Lubuk Alung pada materi Protista dan Fungi dapat dikategorikan baik.

Dari uraian di atas menunjukkan bahwa penggunaan modul pembelajaran biologi berorientasi model siklus belajar yang dikembangkan dapat menumbuhkan sikap-sikap yang harus dicapai pada kompetensi sehingga belajar siswa menjadi lebih baik.

3) Aspek Keterampilan

Penilaian pembelajaran dari aspek keterampilan merupakan penilaian pengalaman belajar melalui keterampilan yang melibatkan kreatifitas, kemampuan dalam melakukan sesuatu dan bisa menghasilkan sesuatu. Menurut Arikunto (2010: 182) penilaian ranah sikap dapat dilakukan terhadap hasil-hasil belajar yang berupa penampilan atau kegiatan selama proses pembelajaran. Penialaian keterampilan dilakukan selama proses praktikum berlansung dengan dua kali pertemuan. Aspek yang di nilai adalah pemilihan alat dan bahan, urutan kegiatan praktikum, dan produk yang berupa hasil pengamatan dan pembahasan dalam bentuk laporan.

Hasi analisis penilaian keterampilan diperoleh rata-rata dengan kategori baik sekali (efektif) mulai dari pemiliahn alat dan baha, urutan kegiatan dan produk. Menurut Lufri (2007: 36), metode eksperimen memberikan kesempatan pada anak didik baik individu maupun kelompok untuk melakukan suatu percobaan di laboratorium atau lapangan, guna membuktikan teori bagi anak didik.

Dari keseluruhan hasil analisis lembar validitas, praktikalitas dan efektivitas dinyatakan bahwa modul pembelajaran biologi berorientasi model siklus belajar yang dikembangkan sudah valid dan praktis. Hal ini telah menjawab permasalahan yang dibatasi pada batasan masalah. Permasalahan tersebut adalah belum tersedianya modul pembelajaran biologi berorientasi model siklus belajar yang valid, praktis dan efektif pada semester I untuk siswa SMA/MA. Modul ini diharapkan dapat digunakan sebagai salah satu bahan ajar oleh guru dan siswa dalam proses pembelajaran biologi. Hal ini sesuai dengan pernyataan Prastowo (2011: 77), bahan cetak adalah sejumlah bahan yang disiapkan dalam kertas yang dapat berfungsi untuk keperluan pembelajaran/penyampaian informasi.

Penelitian ini secara umum berjalan lancar. Waktu pelaksanaan empat kali pertemuan yang sedikit telah diatasi dengan melakukan dua kali pertemuan pada jam belajar dan dua kali pertemuan untuk praktikum pada luar jam belajar dan sekaligus melakukan tes penilaian kognitif.

Kendala penelitian ini adalah pada uji praktikalitas oleh guru, tidak semua guru yang mengisi angket uji praktikalitas mencoba untuk menjadi observer pada setiap kali pertemuan. Hal ini dikarenakan pada saat yang sama guru biologi yang lain mengajar di kelas lain. Akan tetapi, hal ini sudah diatasi dengan bantuan observer lain yang sudah diizinkan oleh guru biologi yang digantikan.

\section{KESIMPULAN}

berikut ini.

Berdasarkan hasil penelitian yang telah dilakukan, diperoleh kesimpulan sebagai

1. Modul pembelajaran biologi berorientasi siklus belajar untuk siswa SMA/MA kelas X semester I yang dikembangkan dengan Model pengembangan IDI Model. IDI Model 
memiliki tiga tahapan secara yaitu Define (pendefenisian) yang merupakan tahapan untuk menentukan masalah dasar, develop (pengembangan) yang merupakan tahapan untuk menyusun bahan yang dibutuhkan dan evaluate (penilaian) yang merupakan tahapan untuk mengetahui efektivitas dan efisiensi bahan.

2. Validitas modul pembelajaran biologi berorientasi siklus belajar yang dihasilkan memenuhi kategori yang valid ditinjau dari kelayakan isi, kebahasaan, penyajian dan kegrafikan modul.

3. Praktikalitas modul pembelajaran biologi berorientasi siklus belajar yang dihasilkan memenuhi kategori praktis oleh guru dan siswa ditinjau dari kemudahan dalam penggunaan, waktu dalam penggunaan dan biaya produksi.

4. Efektivitas modul pembelajaran biologi berorientasi siklus belajar yang dihasilkan memenuhi kategori efektif ditinjau dari motivasi, aktivitas dan hasil kompetensi belajar siswa (pengetahuan, sikap dan keterampilan)..

\section{DAFTAR PUSTAKA}

Aliassyah, M. 2010. PSPB-S1. (Online), (http://maliassyah.blogspot.com/2010/08/pspbsi.html), diakses 20 September 2012.

Arikunto, S. 2010. Dasar-Dasar Evaluasi Pendidikan. Bumi Aksara: Jakarta

Citrawathi M, D. 2006. Pengembangan Pembelajaran Biologi dengan Menggunakan Modul Berorientasi Siklus Belajar dan Pengaruhnya terhadap Hasil Belajar Siswa di SMA. Jurnal Pendidikan dan Pengajaran IKIP Negeri Singaraja. No 3 Th. XXXIX Juli. ISSN $0215-8250$.

Depdiknas. 2008. Panduan Pengembangan Bahan Ajar. Jakarta: Direktorat Jendral Manajemen Pendidikan Dasar dan Menengah.

Djamarah, S. B dan Aswan Z. 2006. Strategi Belajar Mengajar. Jakarta: Rineka Cipta.

Huda, M. 2013. Model-Model Pengajaran dan Pembelajaran. Yogyakarta: Pustaka Belajar.

Lufri. 2007. Strategi Pembelajaran Biologi. Padang: Unp Press.

Prastowo, A. 2011. Panduan Kreatif Membuat Bahan Ajar Kreatif. Yogyakarta: Dirjen Dikti

Purwanto, M. N. 2009. Prinsip-Prinsip dan Teknik Evaluasi Pengajaran. Bandung: PT. Remaja Rosdakarya Offset.

Sadiman, A., Rahardjo, A.H., Rahardjito. 2006. Media Pendidikan. Jakarta: CV. Rajawali.

Sadirman. 2010. Interaksi dan Motivasi Belajar Mengajar. Jakarta: Rajawali Press.

Sanjaya, W. 2008. Perencanaan dan Desain Sistem Pembelajaran. Jakarta: Prenada Media Grup

2010. Strategi Pembelajaran Berorientasi Standar Proses Pendidikan. Jakarta: Prenada Media Grup.

Sudjana, N. 2005. Penilaian Hasil Proses Belajar Mengajar. Bandung: Remaja Rosdakarya. Trianto. 2010. Model Pembelajaran Terpadu. Jakarta: Bumi Aksara.

Wena, M. 2009. Strategi Pembelajaran Inovatif Kontemporer. Jakarta: PT. Bumi Aksara.

Yusnita, E., M. Djahir B, Sri S. 2011. Pengembangan Modul Pendidikan Kewarganegaraan Program Studi Ilmu 